\title{
The Vital Potential of Ayurveda in COVID-19 Pandemic
}

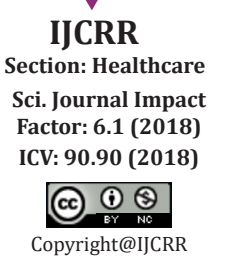

\section{Shikha Pawar ${ }^{1}$, Himanshu Joshi ${ }^{1}$, Deepak Nanda ${ }^{1}$, Navin Kumar ${ }^{2}$}

'College of Pharmacy, Graphic Era Hill University, Bhimtal Campus, Uttarakhand, India; ${ }^{2}$ Department of Biotechnology, Graphic Era Deemed to be University, Dehradun, Uttarakhand, India.

\section{ABSTRACT}

Background: The whole world is facing an unprecedented period of novel coronavirus (COVID-19). Despite the efforts, the disease is continuously spreading. According to world meter, globally there are $6,341,034$ active cases and 746,652 deaths as on 11 August 2020.

Management: The developments of vaccines are underway, in such situation maintaining immunity is the only way to combat this infectious disease. The elements of pandemic require urgent control of all information frameworks accessible internationally. Utilizing the oldest science of medicine, Ayurveda paves away in this pandemic. It gives specific consideration to the host and suggests measures for a sound way of life. Ayurveda defines immunity as the ability to prevent infection and thereby maintain homeostasis.

Conclusion: To deal with this pandemic situation using traditional medicine system, India can prove the strength of Ayurveda.

Key Words: Coronavirus, SARS-CoV-2, Immunity, Traditional medicine, Ayurveda, Yoga

\section{INTRODUCTION}

Coronavirus is a respiratory tract virus which was first identified in 1962 in the people who were suffering from respiratory tract infection. ${ }^{1}$ The virus was not considered fatal until 2002 when several cases of the severe acute respiratory syndrome (SARS) were reported and lead to higher mortality. In 2003, various reports were published stating the spread of coronavirus to the 24 countries of the world including United States America, Singapore, Vietnam, Thailand, Cambodia, Hong Kong, Singapore, Hanoi, Canada and others recording total 8,437 cases and 813 mortality. ${ }^{2-4}$ In December 2019, novel coronavirus (COVID-19) was first identified in a group of pneumonia patients belonging to Wuhan city of China. ${ }^{5-7}$ As thousands of infection cases confirmed across the globe by this newly discovered virus; the World Health Organization declared it as pandemic on 11 March 2020. Since the virus caused infection similar to SARS coronavirus (SARS-CoV) so officially named as COVID-19. ${ }^{8}$

The human race is battling against this tiny enemy which is invisible to the human eye and can attack from anywhere.
Thus made the world frightful and locked them into their homes. As the work on vaccination and medication are underway, so to protect oneself from infection building up the immunity is the only way to combat this virus. Ayurveda, the science of life: is one of the oldest medical systems in the world and traditionally used in India is the only possible medium to enhance immunity. The system of Ayurveda is based on a natural and holistic approach which utilizes the plant-based science. ${ }^{9}$

\section{Genetic structure of coronavirus}

The coronaviruses $(\mathrm{CoV})$ are non-segmented enveloped positive-sense single strands of RNA from 26.4 to 31.7 kilobases which belong to the family Coronaviridae and order Nidovirales. These viruses on electron microscopy appear as a crown (corona in Latin means crown) having club-shaped surface protein projections. ${ }^{10,11}$ They primarily target the upper respiratory tract and further affect the central nervous system, causing long-term neurological damage. ${ }^{12}$ The SARS-CoV-2 virus belongs to $\beta$-coronavirus genus which shows $96 \%$ genome sequence similarity with bat coronavi-

\section{Corresponding Author:}

Dr. Himanshu Joshi, College of Pharmacy, Graphic Era Hill University, Bhimtal Campus, Nainital, Uttarakhand, India Mob: 8217548866; Email:2hjoshi@gmail.com, 2hjoshi@gehu.ac.in

ISSN: 2231-2196 (Print)

Received: 24.07 .2020
ISSN: 0975-5241 (Online)

Revised: 19.09 .2020
Accepted: 10.11 .2020
Published: 07.12 .2020 
rus and $92 \%$ similarity with pangolin coronavirus, ${ }^{13}$ implies that novel coronavirus might have originated from bats.

There are seven coronavirus species ${ }^{14}$ identified to infect human beings include:

1) $\mathrm{hCoV}-229 \mathrm{E}$ (alpha coronavirus)

2) $\mathrm{hCoV}-\mathrm{OC} 43$ (beta coronavirus)

3) hCoV-NL63 (alpha coronavirus)

4) hCoV-HKU1 (beta coronavirus)

5) MERS-CoV: $\beta-\mathrm{CoV}$ (beta coronavirus)

6) SARS-CoV: $\beta-\mathrm{CoV}$ (beta coronavirus)

7) SARS-CoV-2: $\beta-\mathrm{CoV}$ (beta coronavirus)

Most human coronavirus infections are mild but in the last two decades, severe acute respiratory syndrome coronavirus (SARS-CoV) and the Middle East respiratory syndrome coronavirus (MERS-CoV) proved to be more fatal to humans. At present, COVID-19 infection are increasing day by day and proving to be life-threatening to the human race.

\section{Modes of transmission}

An infection occurs when there is an interaction between the host and the pathogen. The transmission of the pathogen can be by:

1. Direct contact

2. Indirect contact

3. Airborne

Indirect contact, the pathogen is transferred between the individuals without any intermediate agent. In indirect contact, the pathogen is transferred via a contaminated intermediate. Whereas in airborne; the transmission of the potentially infectious pathogen occurs through inhalation of droplets. ${ }^{15}$ The novel coronavirus (COVID-19) spread through airborne droplets when a healthy person comes in contact with the person already positive to the virus through sneezing and coughing. Many published articles suggest that the novel coronavirus enter the human body through angiotensin-converting enzyme 2 (ACE 2$)^{16}$ and thus makes one infected.

\section{Clinical features}

The most common clinical features of COVID-19 are fever, cough, sore throat, headache, fatigue, muscle pain and breathlessness. The infection can't be identified in the initial stage as symptoms are similar to other respiratory infection but with time the disease may progress to pneumonia leading to failure of the respiratory system and ultimately leads to death of the patient. ${ }^{17}$

\section{Diagnosis}

The SARS-CoV-2 infection can be detected by specific molecular tests, real-time reverse transcriptase PCR, real-time PCR (RRT-PCR) on samples collected from the nasopharyngeal swab and throat swab. Serological kits are also available from different manufacturing companies which detect $\mathrm{N}$ protein IgM and IgG antibodies present in human blood and serum samples. The imaging techniques utilized for identifying COVID-19 is CT and X-beam of the chest. CT scans are more sensitive and specific and generally shows infiltrates, ground-glass opacities and subsegmental consolidation. CT scan is also abnormal in asymptomatic patients or patients with no clinical evidence. Abnormal CT scans have been used to diagnose COVID-19 in suspect cases with negative molecular diagnosis and found to be positive on repeating the testing.

\section{Immunity}

Immunity is the ability of the body to obstruct the entry of the pathogenic invaders causing any type of disease or infection. A person who has compromised immunity is more susceptible to the infection. In such condition to maintain the immunity is very much important. ${ }^{13}$ Immunity can be a nonspecific or specific type. When the immune system encounters pathogen for the first time; they prevent it by producing a large number of non-specific antibodies. While in specific type, a set of antibodies are produced against pathogens or antigen. ${ }^{18}$

\section{Classification of Immunity}

Immunity can be classified into:

a) Innate Immunity

b) Acquired immunity

Innate Immunity: This type of immunity is the first line of guard against any pathogen. It is the inborn ability of the body to fight against any invading organism. Whenever any micro-organism enters the body, the intrinsic resistance dispenses with it before building up any ailment. Innate immunity also called natural or non-specific immunity. ${ }^{19}$

\section{Acquired Immunity:}

This type of immunity recognizes the attacking micro-organism like viruses, bacteria and so forth known and develops the antibodies specific to that pathogen. Acquired immunity is also known by as specific immunity. Acquired immunity is subdivided into ${ }^{20}$

a) Cellular Immunity

b) Humoral Immunity

\section{a) Cellular Immunity}

This sort of immunity created by T-cells known as the antigen-explicit cells, produced in the bone marrow and found in the circulation system and lymphoid tissue. Whenever Tcells experience antigens introduced over antigen-presenting cells (APCs); they differentiate and multiply to initiate apoptosis. The cytotoxic T-cells, demolish the infected cells in a way to activate plasma B cells by producing IgG and IgM type of antibodies. ${ }^{20}$ 


\section{b) Humoral Immunity}

In humoral immunity, specific reactions are produced against a specific antigen. When all the attacking microbes tend to increase in the extracellular space, humoral immunity gets activated and demolishes the micro-organism by producing specific antibodies against it. The humoral immunity gets activated when the circulating cells bind with the antigen (micro-organism) which activates antibodies producing cells and complement system which in turn recruits the phagocytic cells. These cells engulf the microorganism and the process is called opsonization. ${ }^{21}$

\section{Pathogenesis of Immunity}

Any disease begins when a pathogen recognized by the immune system. The interaction between the pathogen and immune system influences the immune system cells; macrophages release lysosomal enzymes and reactive oxygen species (RO.S.) to remove the microorganism from the host's body. Cytokines are also activated along with leukocytes to remove the pathogens. As the pathogens enter the host body, interferons and natural killer cells demolish the infection tainted cells. This natural response initiates neutrophils against microorganisms. The macrophages ingest the microbes and release the monocyte to the kindled tissue. These process the antigen and produce specialized cells which inhibit the infection with the same micro-organisms. Whenever parasite attacks the human body, eosinophils release their granules to protect against infection. ${ }^{22,23}$

\section{Ayurvedic pathogenesis of immunity}

Ayurveda relies upon the three Doshas i.e., Vata, Pitta, and Kapha (fig 1). These three doshas are balanced in a healthy individual but when these are imbalanced, and then at that point an illness develops. When vrishanu take subsequent passage to a healthy human body, it gets vibhajit in the raktadhatu (blood) and builds up the swasroga and from that point develops vrikkaroga. According to Ayurveda, the pathogenesis of immunity. ${ }^{24}$

- In Dosha, at first Kaphadosha increments and causes the imbalance between Vata and Pitta.

- Dushya: it relies upon the status of Rasa dhatu (blood plasma), which prompts febrile conditions.

- Agni: develops due to the expansion in Kapha Dosh mandagni.

- Ama: if the Samaroga influenced by the Kapha Rog causes indigestion and makes Amaawastha, in an infected individual.

- Srotasmi: for COVID-19 infected individuals, there are two kinds of srotas- Pranavahasrota (respiratory entries) and Rasavahasrotas (blood plasma).

- Srotodushtiprakar: It is sanga which blocks and atipravritti which causes excessive flow.

- Sthana is Udbhavasthana (upper area) and Agantuja (outside factor) when Kapha is present in the chest region of the body.

- Vyakta infects the chest area in which Kapha is present i.e., lungs, sinuses, stomach, heart, blood, joints.

Since no definite treatments are available and preventive measures are the only ways to protect one from getting affected by a novel coronavirus.

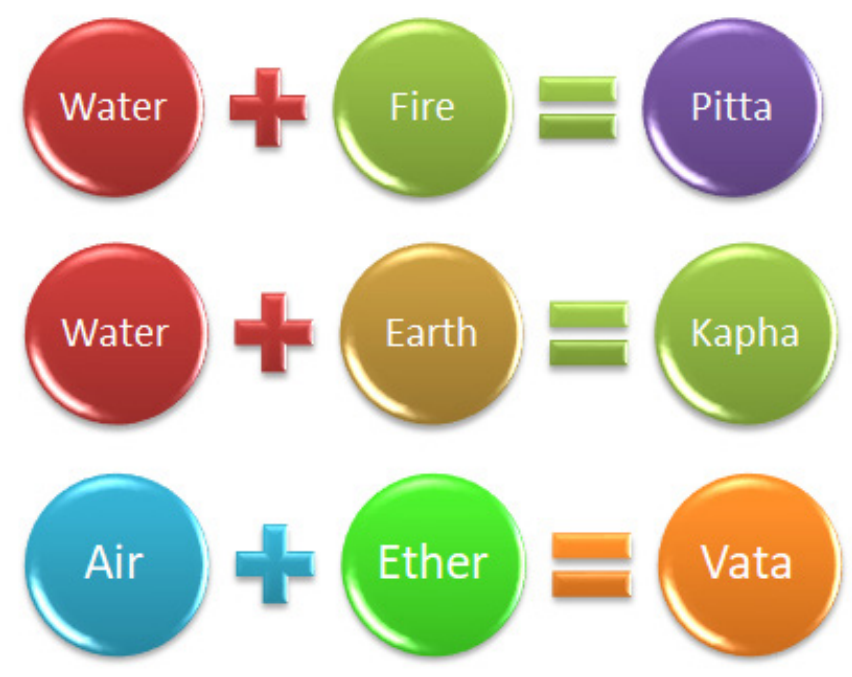

Figure 1: Ayurveda Doshas.

\section{Mode of Transmission: ${ }^{24}$}

According to Ayurveda, the transmission of the disease takes place:

- Prasangat: with close collaboration.

- Gatrasamsparshat: physical contact with unhealthy people.

- Nishwasa: by inhalation of respiratory droplets of an infected individual.

- Sahabhojanat: sharing food.

- Sahashayya: resting together.

- Asana: sitting near one another.

- Vastra: sharing the same apparel.

- Malya: using tissue and towels.

\section{Preventive measures ${ }^{26,27}$}

Following appropriate precautionary measures can prevent the spread of COVID-19:

- Regularly cleaning hands with soap and water or using an alcohol-based $(70 \% \mathrm{v} / \mathrm{v})$ hand rub.

- Maintaining a safe distance form individual who is coughing or sneezing.

- Wearing a face mask and keeping respiratory hygiene.

- Cleaning the surfaces with disinfectant on regular basis.

- Face masks and respiratory hygiene 
- Self-isolation if an individual feels unwell.

\section{Management}

\section{Therapeutic treatment ${ }^{24}$}

- SarveAbhyanga: is the whole body oil massage with Dhavantaramtaila, Dashmooladitaila, or karpooraditaila with rock salt Rukshasweda (dry warmth), nadisweda (steam managed locally through cylinders).

- PindaSweda (a hot herbalized rice balls) is applied over chest and back also used in the treatment.

- Vamana is done in a controlled way by a particular mix of Madanaphala decoction, yastimadhu, and Vacha.

- Anuvasana (oil-based douch) and Niruhabasti (decoction-based douches) are used for their laxative action.

- Nasal application of coconut oil or ghee in the nostrils is one of the suggested methods.

\section{Ayurvedic Herbs/ herbal formulation for main- taining immunity 28-30, 32}

To maintain good health and prevent infection, detoxification is an exceptionally fundamental part which expels out the impurities and keeps the individual healthy. Various herbs/ herbal formulations (given in Table 1) suggested by AYUSH which assist in the detoxification are as follows:

\section{Table 1:Various herbal formulation.}

- Consuming homegrown tea prepared from madhuyashti, basil, peppermint and vasa with honey.

- Intake of salad made from boiled beetroot, radishes, cabbage and broccoli

- Decoction prepared from tulsi, ginger, pepper, and turmeric also boost immunity.

Kashayam of Guduchi spice and SendhilKodi powder in boiling water improves immunity and lowers fever.

- Hot Milagu and SeeragamRasam are additionally helpful in your day by day diet.

- Chyavanprash 1 tablespoon daily can likewise be utilized for boosting the resistance.

- Lemon juice is a good source of vitamin $C$ also keeps the body healthy.

- Taking Kadha (decoction) of Tulsi, Daalchini, Kaalimirch, Shunthi, Munakka every day serve the purpose.

- Taking milk with Haldi also suggested decreasing the susceptibility of the body to infection.

- A clove blended with nectar relieves the irritation in the throat or dry cough.

- AYUSH 64, ashwagandha, yashtimadhu, Guduchi and pippali, tulsi, ginger, Guduchi are some of the ayurvedic drugs help in developing resistance.

\section{Yoga and Pranayama ${ }^{30,31}$}

In India, yoga is practised and taught since ancient times. Yoga is a form of physical exercises (asana) and breathing exercises (pranayama). This holistic science of yoga help in stress management related disorders and promote immunity. Many research studies suggest positive health attributes of yoga Various yoga asana helps in improving physical and mental health. In this pandemic, SudarshanKriya yoga is the solution to boost immunity. It comprises of pranayama, yoga and meditation which improves the defence mechanism of the body. Daily practice for 20 minutes improves the immunity and makes an individual physically, mentally and emotionally strong.

Routinely practices of breathing exercises (pranayamas) strengthen the lungs and also improve immunity as the novel coronavirus attacks the respiratory system. Such pranamayas are beneficial and also have a positive impact on psychological and physical well-being.

Ujjayi Pranayama: This form of pranayama is the most common. In this, breathing is mainly focused at the base of the throat to increase the intake of oxygen.

Kapalbhati Pranayama: This yogic breath keeping people healthy since ages. It is a part of eight limbs of yoga, compiled by Yoga Sutras by Sage Patanjali. This technique flushes out toxic air from the body and keeps mind, body and spirit healthy.

NadiShodhan Pranayama: In this pranayama, individual concentrate on the normal breath for a few minutes and close right nostril with the thumb and breath through the left nostril. Alternatively, repeat the same process for left nostril. This strengthens the respiratory system and calms the mind.

\section{CONCLUSION}

The world is fighting to discover an answer for ending the pandemic as it has caused numerous causality due to the absence of defined treatment available. As prevention is better than cure, the Vedic science of Ayurveda narrates the preventive aspect of infectious diseases and focuses on building up immunity. It helped in developing resistance to the viruses and reduces the susceptibility to the infection; also prevent the deterioration of disease to a critical state. There is an incredible requirement for research on Ayurvedic drugs for future procedures to fix the pandemic like situation for the benefit of mankind.

\section{ACKNOWLEDGEMENT}

We gratefully thank Graphic Era Hill University for all support and encouragement for writing this review. 
Conflict of Interest: The authors declare that there are no conflicts of interest.

\section{Financial Funding: None.}

\section{REFERENCES}

1. Sahin AR, Erdogan A, Agaoglu PM, et al. 2019 novel coronavirus (COVID-19) outbreak: a review of the current literature. EJMO 2020; 4:1-7.

2. World Health Organization. The cumulative number of reported probable cases of SARS. 2003. https://www.who.int/csr/sars/ country/2003 07 11/en/. Accessed on 10 June 2020.

3. Weiss SR, Leibowitz JL. Coronavirus pathogenesis. Adv Virus Res 2011; 81:85-164.

4. Pal M. Severe acute respiratory syndrome: a newly recognized viral zoonosis of public health concern. Acta Sci Microbio 2018; $1: 1$.

5. Lu R, Zhao X, Li J. Genomic characterization and epidemiology of 2019 novel coronavirus: implications for virus origins and receptor binding. Lancet 2020; 395:565-574.

6. World Health Organization. Coronavirus disease (COVID-19) pandemic.2020. https://www.who.int/emergencies/diseases/ novel-coronavirus-2019. Accessed on 12 June 2020.

7. $\mathrm{Xu} X W, \mathrm{Wu} \mathrm{XX}$, Jiang $\mathrm{XG}$. Clinical findings in a group of patients infected with the 2019 novel coronavirus (SARSCov-2) outside of Wuhan, China: retrospective case series. BMJ 2020;368:m606.

8. Chen Y, Liu Q, Guo D. Emerging coronaviruses: genome structure, replication, and pathogenesis. J Med Virol 2020; 92:418423.

9. National Centre for Complementary and Integrative Health. 2020. https://www.nccih.nih.gov/. Accessed on 1 July 2020.

10. Ksiazek TG, Erdman D, Goldsmith CS et al. A novel coronavirus associated with the severe acute respiratory syndrome. $\mathrm{N}$ Engl J Med 2003; 348:1953-1966.

11. Interim guidance for environmental cleaning in non-healthcare facilities exposed to SARS-CoV-2. ECDC technical report. 2020. https://www.ecdc.europa.eu/sites/default/files/documents/coronavirus-SARS-CoV-2guidance-environmental-cleaning-non-h. Accessed on 7 July 2020.

12. Tabish SA. Response to the challenge of coronavirus (2019nCoV) pandemic. Technical Report 2020.

13. Larissa H. Immune System. 2019. https://kidshealth.org/en/parents/immune.html. Accessed on 9 July 2020.

14. Centers for disease control and prevention. Coronavirus. 2020. https://www.cdc.gov/coronavirus/types.html. Accessed on 15 June 2020.

15. Centers for disease control and prevention. How infections spread. 2016. https://www.cdc.gov/infectioncontrol/spread/index.html\#tbs-2-2. Accessed on 17 July 2020.

16. Letko M, Marzi A, Munster V. Functional assessment of cell entry and receptor usage for lineage B $\beta$-coronaviruses, including 2019nCoV. Nat Microbio 2020;5:562-569.
17. TanuSinghal. A Review of Coronavirus Disease-2019 (COVID-19). Indian J Pediatr 2020; 87(4):281-286.

18. Goldsmith CS, Tatti KM, Ksiazek TG, Rollin PE, Comer JA, Lee WW, et al. Ultrastructural characterization of SARS coronavirus. Emerg Infect Dis 2004; 10 (2): 320-26.

19. Estola T. Coronaviruses, a New Group of Animal RNA Viruses. Avian Dis 1970; 14 (2): 330-336.

20. Kahn JS, McIntosh K. History and recent advances in coronavirus discovery. Pediatr Infect Dis J 2005; 24(11): S223-7.

21. Mahase E. COVID-19: Coronavirus was first described in The BMJ in 1965. BMJ 2020; 16;369: m1547.

22. JustizVaillant AA, Jan A. Physiology, Immune Response. In: StatPearls. Treasure Island (FL): StatPearls Publishing; 2020 Jan. https://www.ncbi.nlm.nih.gov/books/NBK539801/. Accessed on 10 August 2020.

23. Editorial. Pathogenesis: Of host and pathogen. Nat Immunol 2006;7(3): 217.

24. The Gerson Institute of Ayurvedic Medicine. 2020. https:// www.gersonayurveda.com/giamblog/2020/4/6/the-ayurvedicapproach-tocoronavirus-pathogenesis-possible-preventionandtreatment. Accessed on 5 August 2020.

25. Wikipedia. Covid-19 pandemic 2020. https://en.wikipedia.org/ wiki/COVID-19_pandemic. Accessed on 29 July 2020.

26. World Health Organization. Coronavirus disease (COVID-19) advice for the public. 2020. https://www.who.int/emergencies/ diseases/novel-coronavirus-2019/advice-for-public. Accessed on 1 August 2020.

27. More SM, Kharwade RS. Coordinated roadmap to grip Pandemic COVID-19. Coronaviruses 2020; 1. 10.2174/2666796701999 200801023110.

28. Venugopa V. Coronavirus outbreak: Ayush pushes 'traditional cure', med council backs modern drugs. The Economic Times. 2020. https://economictimes.indiatimes.com/news/politicsand-nation/ayush-pushes-traditional-cure-med-council-backsmodern-drugs/articleshow/74680699.cms. Accessed on 28 May 2020.

29. Charak Samhita. JwaraChikitsa. 2018.http://www.carakasamhitaonline.com/mediawiki-1.32.1/index.php?title=Jwara_Chikitsa. Accessed on 28 July 2020.

30. Art of living. 2020.https://www.artofliving.org/inen/ayurveda/ coronavirus-prevention. Accessed on 20 April 2020.

31. Sengupta P. Health Impacts of Yoga and Pranayama: A State-ofthe-Art Review. Int J Prev Med 2012; 3(7): 444-458.

32. Is Ayurveda the key to combat Coronavirus pandemic? Here's all you need to know. ABP Live. 2020. https://news.abplive. com/news/India/coronavirus-outbreak-is-ayurveda-key-combat-covid-19pandemic-1194698. Accessed on 12 August 2020.

33. D. Srinivasa R, Ch. R, K. Santa R. A Study on Covid-19 Situation in Andhra Pradesh: Current Scenario and Projections. Int J Cur Res Rev 2020; 12(17): 45-50. 